\title{
REVIEW
}

\section{TYPHOID FEVER AS CELLULAR MICROBIOLOGICAL MODEL}

Dahir Ramos de ANDRADE \& Dahir Ramos de ANDRADE JÚNIOR

\begin{abstract}
SUMMARY
The knowledge about typhoid fever pathogenesis is growing in the last years, mainly about the cellular and molecular phenomena that are responsible by clinical manifestations of this disease. In this article are discussed several recent discoveries, as follows: a) Bacterial type III protein secretion system; b) The five virulence genes of Salmonella spp. that encoding Sips (Salmonella invasion protein) A, B, C, D and E, which are capable of induce apoptosis in macrophages; c) The function of Toll R2 and Toll R4 receptors present in the macrophage surface (discovered in the Drosophila). The Toll family receptors are critical in the signalizing mediated by LPS in macrophages in association with LBP and CD14; d) The lines of immune defense between intestinal lumen and internal organs; e) The fundamental role of the endothelial cells in the inflammatory deviation from bloodstream into infected tissues by bacteria. In addition to above subjects, the authors comment the correlation between the clinical features of typhoid fever and the cellular and molecular phenomena of this disease, as well as the therapeutic consequences of this knowledge.
\end{abstract}

KEYWORDS: Typhoid Fever; Salmonella enterica serovar Typhi; Cellular Microbiology; Bacteria-Cell interaction.

Classically, typhoid fever is considered a disease of multiple stages: 1) the first week is characterized by progressive elevation of the temperature, followed by bacteremia; 2) the second week comes with rose spots in the skin, abdominal pain, and splenomegaly; 3) the third week marks a more intensive intestinal inflammatory process, particularly in the Peyer's patches, and complications may develop as digestive bleeding and intestinal perforation. The patients may have clinical recovery afterwards. However, some patients may die after a progressive clinical worsening not responsive to the treatment with antibiotics against Salmonella enterica subsp. enterica serovar Typhi (S.Typhi).

The knowledge about typhoid fever pathogenesis has grown in the last years, mainly about the cellular and molecular phenomena that are responsible by clinical manifestations of this disease. In this article are discussed some recent discoveries about Salmonella spp. as follows: a) bacterial type III protein secretion system (TTSS); b) the five virulence genes (A, B, C, D and E) of Salmonella spp. that encoding Sips (Salmonella Invasion Proteins); c) Toll R2 and Toll R4 receptors present in the macrophage surface, that are critical in the signalizing mediated by LPS in macrophages; d) the lines of immune defense between intestinal lumen and internal organs; e) the fundamental role of the endothelial cells in the inflammatory deviation from bloodstream into infected tissues by bacteria. With the new discoveries about typhoid fever pathogenesis, we consider this disease as an authentic cellular microbiological model of study.
The knowledge about typhoid fever raises some doubts. The use of microbicide therapeutic should be evaluated in relation to the risks of disease worsening because of elevation of the lipopolysaccharide (LPS) molecules. These molecules are called as LPS/endotoxin, and they are responsible for the mononuclear cell activation that release cytokines as TNF-alpha, IL-1, IL-6, IFN-gamma, etc.

LPS is considered a powerful agent for the inflammatory cells activation, and it acts through CD14, Toll R2 and Toll R4 receptors. Through them, LPS transmits signals to intracellular protein chain known as p21 activated kinase (PAK) studied in Salmonella enterica serovar Typhimurium (S.Typhimurium $)^{10}$. Other proteins activated by $\mathrm{S}$. Typhimurium are the Rho-GTPases that are capable to stimulate the membrane "ruffling" (the rearrangement of cellular membrane), through which Salmonella spp. entry into the cells. At this moment, the rearrangement of actin cytoskeleton and the nuclear responses also happens.

The contact of cytosol with proteins secreted by invasive bacteria (S.Typhi, S.Typhimurium, S. Cholerae-suis, etc.) is made through protein channels named type III secretion system (TTSS) that translocate bacterial proteins inside of the cells. The genetic acquisition of TTSS was a major evolutionary leap for gram-negative bacterial pathogens. TTSS allow animal and plant pathogens to inject their own proteins, termed effectors, directly into host cells and that modulate specific host cellular functions ${ }^{27}$. 
These 'molecular syringes' and their secreted effectors are essential virulence determinants. The protein Sop E is substratum of this secretion system, and it stimulates the cytoskeleton reorganization followed by the JNK protein chain activation, which is dependent of Rac-1 and CDC $42^{19}$. MAP kinases's role in the nuclear responses and cytokines production induced by inflammatory cells and by cultured intestinal cells were discussed in another study ${ }^{22}$. These recent publications about mechanisms of Salmonella spp. action highlightes the knowledge of the evolution of molecular and cellular phenomena in the human typhoid fever. These phenomena are the base of disease's symptoms and clinical manifestations.

\section{TYPHOID FEVER PATHOGENESIS}

1) Intestinal mucosal Immunity (first line of defense): The infectious dose of S.Typhi in volunteers varies between 1000 and 1 million organisms $\mathrm{s}^{25}$. This bacterium must survive the gastric acid barrier to reach the small intestine, and a low gastric $\mathrm{pH}$ is an important defense mechanism. In the small intestine, S. Typhi moves across the intestinal epithelial cell (CEI) and reach the M cells, thus penetrating in the Peyer's patches. The M cells, specialized epithelial cells overlying Peyer's patches, are probably originated from CEI and small pockets in the mucosal surface characterize them. After contact with $M$ cells, the infectious agents are rapidly internalized and they reach firstly a group of antigen-presenting cells (APCs), being partially phagocytized and neutralized. Some bacteria escape of this barrier, and they reach the welldeveloped lymphoid follicles (Peyer's patches), formed mainly by mononuclear cells as T lymphocytes, as well as dendritic cells. Dendritic cells present the bacterial antigens and they provoke $\mathrm{T}$ and $\mathrm{B}$ lymphocytes activation.

2) Dissemination from intestinal mucosa's lamina propria: Starting from lamina propria, $\mathrm{T}$ and B lymphocytes activated come out for the lymphatic nodules. They will reach the mesenteric veins through lamina propria blood vessels, and then they arrive to liver and spleen. In these organs, the bacteria are destroyed mainly after phagocytosis by macrophage system. However, Salmonella spp. organisms are able to survive and multiply within the mononuclear phagocytic cells ${ }^{26}$.

At a critical point determined by the number of bacteria, the bacterial virulence and the host immune response, bacteria are released from their sequestered intracellular habitat into the bloodstream. This bacteremic phase of disease is characterized by widely dissemination of the organisms. The most common sites of secondary infection are the liver, spleen, bone marrow, gallbladder and Peyer's patches in the terminal ileum. In the liver, S. Typhi provokes Kupffer cells activation. Kupffer cells have high microbicide power, and they neutralize the bacteria with oxidative enzymes (via oxygen free radicals, nitric oxide, etc.), as well as enzymes active in acid $\mathrm{pH}$. These cells constitute the most effective barrier to invasive bacteria as S. Typhi and S. Typhimurium. The survivor bacteria reach and invade hepatocytes, and they will cause high cellular death rate, mainly apoptosis ${ }^{3}$. The apoptosis occurs through activated kinases that phosphorylase protein responsible for signs transmission to the nucleus. In our laboratory, we could verify that the rat hepatocytes produce TNF-alpha in a time-dependent and progressive form when invaded by S. Typhimurium ${ }^{4,5}$. This phenomenon is very important, since the TNF-alpha is capable to amplify the local inflammatory response and to induce the hepatocyte death by apoptosis.
3) Main host immune defense: The main host defense against Salmonella spp. occurs through the neutrophils at first, followed by mononuclear cells. These inflammatory cells produce cytokines as Tumor Necrosis Factor alpha (TNF-alpha), Interferon-gamma (IFN-gamma), IL-1, IL-2, IL-6 and IL-8. The Kupffer cell is the main TNF-alpha producer in the liver. Several studies have shown that epithelial cells play a central role in coordinate the intestinal inflammatory response to intestinal pathogens. The interaction of Salmonella spp. with epithelial cells leads to the generation of a great number of biochemical signals by these cells. These include the basolateral release of chemokines (including IL-8) and apical secretion of "pathogen - elicited epithelial chemoattractant" (PEEC) ${ }^{13,33}$. These substances are partially responsible for guide the recruitment and traffic of PMNs across CEIs. In recent study was showed that S. Typhimurium induces IL-8 secretion by intestinal epithelia through increase in intracellular calcium. This phenomenon was NF-kappaB dependent ${ }^{18}$. A functional TTSS is required for the induction of PMN transmigration. Furthermore, protein synthesis in both bacteria and epithelial cells is also required for this activity. Invasion of Salmonella spp. into epithelial cells is insufficient for transepithelial signaling to PMNs, and PMN migration occurs even when Salmonella spp. invasion is blocked ${ }^{17}$.

The "inflammatory deviation" that happens when blood leukocyte migrates across endothelial cells into hepatic and spleen tissues is another important event. This phenomenon occurs through the action of adhesion molecules named integrins (chain $\alpha \beta$ ) in inflammatory cells and selectins in endothelial cells (E and P). Afterward, selectins are substituted by ICAMs and VCAMs proteins (whose partner in inflammatory cells is VLA 4 or $\alpha 4 \beta 1$ integrin). The inflammatory microenvironment is completed by chemokines that are capable to stimulate leukocyte motility (chemokinesis) and directed movement (chemotaxis) of neutrophils and mononuclear cells. Chemokines bind to $\mathrm{CC}$ and $\mathrm{CXC}$ receptors in the surface of inflammatory cells. The chemokines help the blood leukocytes migration straight for host cells infected by bacteria.

TNF-alpha is a cytokine produced by macrophages and other mononuclear cells, and it has the greater antibacterial agent against Salmonella spp. TNF-alpha in association with IFN-gamma, IL-2 and other cytokines, will be responsible for the neutralization of this invasive bacteria, besides the macrophage phagocytosis.

4) Apoptosis and the human Toll receptor activated in typhoid fever: Typhoid fever disease is an important example of severe sepsis, because it presents enormous amount of cellular death (necroapoptosis) besides severe toxemia ${ }^{32}$. In this way, there are newest discoveries about the Toll R2 and Toll R4 receptors studied in Drosophila.

The innate immune system uses Toll family receptors to sign microbes presence and to start host defense. Bacterial lipoprotein (BLP) expressed in all bacteria species are potent activators of "Toll-like receptor 2" (Toll R2). The innate immune system includes macrophages and natural killer (NK) cells that act directly on pathogens through cytokines and other stimulatory molecules, which activate the adaptive immune responses (cellular and molecular) through $\mathrm{T}$ and $\mathrm{B}$ lymphocytes ${ }^{35}$. The innate immune system (first line of defense) identifies the pathogens by standard recognition receptors, which attach to microbial macromolecules. In this way, macrophage mannose receptors attach to structures with repeats of polimannose. CD14 receptor, described some time ago, was considered 
as fundamental to recognize LPS/endotoxin in the surface of gramnegative bacteria like Salmonella spp. before the discovery of the Toll $\mathrm{R} 2$ receptor. The difference between $\mathrm{CD} 14$ and Toll $\mathrm{R} 2$ is that the former are a "GPI" (glycosyl-phosphatidylinositol) receptor, that does not cross the cellular membrane, and does not transmit signs for cytoplasm or activate protein chains of macrophages ${ }^{23,35}$. In contrast, Toll R2 molecule cross the cellular membrane, and transmits signs for the intracellular protein chains. The activation of these protein pathways will spread to transcriptional factor NF-kB that will migrate to cellular nucleus starting from cytoplasm. NF-kB recognizes and liberates genes encoding the adhesion molecules, TNF- alpha and another Th1 cytokines (IFN-gamma, IL-2, etc.). The patients with failure of immune response to combat the infection by macrophage activation may evolve to septic shock ${ }^{37}$.

The pathogens have molecular antigens that are recognized by receptors as: LPS of gram-negative bacteria, glycolipid of mycobacteria, lipoteichoic acid of Gram-positive bacteria, mannans of yeast, RNAs of virus and others ${ }^{28,34}$.

Two LPS binding protein, BPI (bactericide permeability increasing protein) and LBP (lipopolysaccharide binding protein) have fundamental importance, because their connection with LPS results in distinct effects. BPI $(55 \mathrm{kD})$ has an antimicrobial role and it is present in neutrophils with selective toxicity against gram-negative bacteria. This protein is more effective when acts on neutrophils phagocytosis in synergism with defensins (intestinal mucosa's antimicrobial). LBP increases the sensitivity to LPS allowing that effector cells are activated by subpicomolar LPS concentrations. LBP recognizes Lipid A, that is the half biologically active of the endotoxin molecule ${ }^{42,43}$. LBP also carry out an important role in the bacterial clearance of peripheral blood through CD14.

Recently, some studies indicate that Toll family receptors (TLRs) are critical in the signalizing mediated by LPS, in association with LBP and $\mathrm{CD} 14^{23}$. The identification of a Toll human receptor homologous (well known in Drosophila) named as hTLR4 (Toll-like human receptor 4), was a great discovery in knowledge on the complex binding receptor with LPS $^{34}$.

Nowadays six members of the "TLRs" family are known, and two of them TLR2 and TLR4 were associated with LPS signalizing. However, only TLR4 has been considered a LPS signalizing in humans $s^{8,21,41}$.

The hTLR4 protein has a repetitive sequence rich in leucine in its extracellular domain that interacts with complex CD14 - LPS. TLR4 and other TLRs have a TIR cytoplasmic receptor (Toll-IL-1 receptor) $)^{1,2,39}$ in homologous domain to IL-1 receptor (IL-1R). This domain communicates with an adapting protein My D88 (myeloid differentiation factor 88) that interacts with TLR4 starting cell signalizing as follows: IL-1R associated kinase (IRAK-1), TNF-alpha receptor (TNFR) associated factor 6 (Traf-6) and NF-kB inducing kinase (NIK). The kinases IRAK-1 and NIK phosphorylase inactive complex in the cytoplasm named IkBs (IKK $\alpha$ and IKK $\beta$ ), causing its degradation through ubiquination-proteasome. This reaction releases the NF-kB/REL dimer, and NF-kB migrates for nucleus when immunomodulatory genes will be activated. In consequence, there is synthesis of cytokines, adhesion molecules (ICAMs), stress proteins (HSPs), and activation of inhibitor of apoptosis genes (IAPs). TLR2 transmits a proapoptotic sign via death receptors and FADD protein (Fan-associated death domain). FADD through death domain contacts homologous area in caspase- 8 prodomain, that cleaves effective caspases 3 and 7 and activate the apoptosis $\operatorname{program}^{1,2}$. This final connection, bind TLR2 to cell apoptosis machine ${ }^{2}$.

5) Protein secretion mechanisms and other virulence mechanisms of Salmonella: Bacteria as Salmonella spp. ${ }^{6,38}$ have type III secretion system that to permit for they inject bacterial proteins in several host cells, such as: CEIs, hepatocytes, endothelial cells and inflammatory cells (neutrophils, monocytes-macrophages, $\mathrm{T}$ and $\mathrm{B}$ lymphocytes etc. ${ }^{20}$.

Recent progresses in cellular microbiology ${ }^{15}$ have highlight the role of type III secretion system as a protein secretion system highly specialized found in gram-negative pathogens. As mentioned above, this system transfers proteins from bacterial cytoplasm into the host cell cytoplasm, with purpose of interfere in the host cellular function.

TTSS includes more than 20 proteins, and it is considered the most complex bacterial protein secretion system associated with the pathogen virulence. The structural components of TTSS can be divided in two groups. One group consists of outer membrane proteins (including one similar to secretin family), and the other group has several integral membrane proteins (similar to flagellar export apparatus). Supramolecular structure associated with TTSS of S. Typhimurium was visualized by electronic microscopy. This structure consists of a needle complex, spans both the inner and outer membranes of bacterial envelope. The needle complex has a long hollow structure about $120 \mathrm{~nm}$ long and it is composed of two domains. The first is a needlelike portion projecting outward from the bacteria surface and the second portion has a cylindrical base that anchors the structure to inner and outer membranes.

The biochemical analysis revealed that the needle complex is composed of three proteins: InvG (a member of secretin family), $\operatorname{PrgH}$ and PrgK (lipoproteins). TTSS is an ATP - dependent system. S. Typhimurium injects in host cells a set of effectors proteins inducing actin cytoskeleton rearrangements, membrane ruffling and macropinocytosis that finish in bacterial invasion. The effectors proteins include an exchange factor for Rho GTPases (Sop E), an inositol phosphate phosphatase (Sop B), and an actin-binding protein (Sip A) ${ }^{44}$. Sop E acts as an exchange factor for a subset of Rho GTPases, including CDC42 and Rac. SopE and possibly other Sops induce enterocyte membrane ruffling promoting bacterial cellular invasion. Sop B modulates the actin cytoskeleton through its inositol phosphate phosphatase activity, which generates a broad range of inositol phospholipids and inositol phosphates. The intracellular SopB protein affects inositol phosphate signalling events. One such event is a transient increase in concentration of Ins $[1,4,5,6] \mathrm{P}_{4}$, which can antagonize the closure of chloride channels, influencing net electrolyte transport and fluid secretion. Sip A inhibits the F-actin depolymerization after its binding to actin. Pathogen-induced remodeling of the host cell actin drives internalization of invasive Salmonella by non-phagocytic CEIs.

Two Salmonella actin-binding proteins are involved in bacterial internalization: SipC that is essential for the internalization process, and SipA that enhances its efficiency ${ }^{44}$.

S. Typhi and other Salmonella serovars have two phenotypes associated with TTSS: one is involved in bacterial invasion to 
nonphagocytic cells, as well as induction of apoptosis in macrophages through Sip $\mathrm{B}^{21}$; the other is required for bacterial survival inside macrophages and for systemic infection.

Nowadays, a new group of virulence genes has been identified in Salmonella, named Sips (Salmonella invasion proteins) containing five genes: Sip A, Sip B, Sip C, Sip D and Sip E. Sip B gene encodes Sip B protein that is involved in proteins translocation via TTSS, and it has potential to induce apoptosis in macrophages through caspase- 1 activation. This fact was showed through Sip B injection in macrophages, which caused apoptosis by caspase- 1 activation $^{36}$. In Salmonella, however, Sip B role inducing apoptosis and concomitant release of IL-1 beta (proinflammatory cytokine) is unclear (in contrast to Shigella).

Another peculiar aspect of Salmonella was showed by ECKMANN et al. ${ }^{14}$. In this study, the CEIs invaded by Salmonella increased the cytokines mRNAs expression as G-CSF, IL-8, MIP-2 $\alpha$, and transcription factors as IRF-1 and NF-kB, as well as HLA class I. These discoveries allow understanding better the bacteria - cell interaction.

Recently, HOOPER \& GORDON ${ }^{24}$ showed that serovars of avirulent Salmonella spp. are capable to inhibit cytokines production by CEIs. This phenomenon involves IkB that blocks the NF-kB migration to nucleus. The avirulent Salmonella inhibited the IkB ubiquination and its degradation by proteasome $26 \mathrm{~S}$. Thus, genes transcription managed by NF-kB was blocked. These genes encode proinflammatory mediators as cytokines, chemokines and adhesion molecules.

The knowledge of bacterial pathogenesis was increased by virulence genes discovery, which are acquired by pathogens and introduced in bacterial DNA. Nowadays, these genes are known as "pathogenicity islands" (PAIs) involving a great genetic area with more than 100 kilobases (kb). Five PAIs have been identified in the Salmonella species. Two of these PAIs, Salmonella pathogenicity island (SPI)-1 and SPI-2, encode TTSS, which are essential virulence determinants. SPI-1 and SPI-2 are expressed under distinct environmental conditions: SPI-1 is induced after initial contact with the host cell, whereas SPI-2 is induced intracellular. In spite of bacterial diversification, gene transfer capacity to become a microorganism of success is variable. In Salmonella are necessary five pathogenicity islands for disease evolution ${ }^{40}$. In contrast, in Escherichia coli one pathogenicity island is enough to increase bacterial virulence.

6) Clinical manifestations of typhoid fever and their pathogenesis: S. Typhimurium and other serovars causes gastroenteritis with intestinal acute inflammation of limited duration in people with normal immune defense. S. Typhi is responsible for typhoid fever in humans, a disease with high clinical toxicity and possible evolution to death $^{6,38}$.

The symptoms and clinical signs in patients with typhoid fever are related to cellular microbiological phenomena ${ }^{12}$. The bacterial invasion of several host cells and the inflammatory response (neutrophils, monocytes-macrophages, $\mathrm{T}$ and $\mathrm{B}$ lymphocytes) with high cytokines production are important elements causing the clinical manifestations. Cytokines produced (IL-1, IL-6, TNF-alpha, Interferons - $\alpha, \beta$ and $\gamma$ ) are also responsible for fever emergence, with four weeks length in the typhoid fever without treatment.
The potent inflammatory reaction against Salmonella spp. has the inconvenience of to provoke the host cells death, as well as the apoptosis of both inflammatory and epithelial cells. This phenomena result in the appearance of several clinical signs as fever, jaundice (due to hepatocytes death and cholangiocytes activation), and increase of enzymes AST, ALT, $\gamma$-glutamyltranspeptidase, alkaline phosphatase, etc. The aminotransferases rise in moderate levels (100 to $300 \mathrm{UI} / 1)$, and $\gamma$ glutamyltranspeptidase and alkaline phosphatase (markers of activated cholangiocytes) may reach 50 to $300 \mathrm{UI} / \mathrm{l}$. These latter two enzymes are situated in the biliary cell membrane.

The increase of cytokines in the peripheral blood will cause fever after incubation period of 5 to 21 days. Initially the fever is low grade, but it rises progressively, and by the second week it is often high and sustained $\left(39^{\circ} \mathrm{C}\right.$ to $\left.40^{\circ} \mathrm{C}\right)$. The fever occurs in more than $80 \%$ of patients in both sexes ${ }^{31}$, with men predominance. The classic disease description includes bacteremia and fever during the first week, as well as nonspecific symptoms as chills, headache, anorexia, sore throat, myalgia, psychosis and mental confusion in 5 to $10 \%$ (typhoid state). A coated tongue, tender abdomen, hepatomegaly, and splenomegaly are common. In the second week, a few rose spots, blanching erythematous maculopapular lesions, approximately 2 to $4 \mathrm{~mm}$ in diameter appear in 5 to 30 percent of cases. They usually occur on the abdomen and chest and more rarely on the back, arms, and legs. A relative bradycardia in relation to fever, intestinal constipation, and diarrhea in smaller number of patients (mainly in young children and adults with HIV infection) may occur. This classic pattern of typhoid fever has been modified by earlier diagnosis and more effective treatment. In spite of these advances, some patients still may present the clinical manifestations of first and second weeks. In the cases without treatment or correct diagnosis, the typhoid fever prolongs to third week. In this period, the inflammatory lesions are intense in Peyer's patches and intestinal lamina propria (with abundant monocytes, macrophages and lymphocytes). There is lymphoid hyperplasia in the ileocecal area followed by ulceration and necrosis (cellular death), with subsequent gastrointestinal bleeding or intestinal perforation. Complications occur in 10 to 15 percent of patients and they can evolve to death, in general after the third week of disease. Symptoms as anorexia, weigh loss, intense weakness, mental confusion, and others, may occur in typhoid fever especially when there is a delay in the diagnosis and treatment.

Relapse of disease occurs in 5 to 10 percent of patients, usually two to three weeks after the fever resolution. The high fever and progressive abdominal pain appear again. This phenomenon may be owing to secondary bacteremia from normal enteric flora due to Peyer's patches inflammation. The fever declines in the 4th week of disease in $90 \%$ of survivors, without antibiotic therapy. However, weakness and weight loss may persist during many months. Pyogenic meningitis, acute cholangitis and mural endocarditis are rare manifestations of typhoid fever. The immune response against $\mathrm{S}$. Typhi has probably similar influence in all these clinical conditions.

The true "sepsis", which constitutes the severe typhoid fever disease, is caused by LPS/endotoxin molecules that are abundant in the surface of Enterobacteriaceae as Salmonella spp., Escherichia coli, etc. These molecules are capable to activate the macrophages, through cell surface receptors known like CD14, Toll R2 and Toll R4 (in humans) as mentioned above. The inflammatory response of Th1-dominant type is 
destructive for host cells and for bacteria. Th1 response attenuates progressively, and this coincides with increase of Th2- immune response. Th2 cells produce IL-4, IL-10, IL-13, TGF- $\beta$, that causes a powerful protecting effect in the host cells (hepatocytes, CEIs, inflammatory cells etc.), through the partial inhibition of cytokines associated with Th1 cells. The predominance of Th1 immune response can be detected by the immunohistochemistry technique with specific antibodies. Another available technique is bioassay or immunoassay that detect cytokines (as IFN-gamma) in peripheral mononuclear cells by the flow cytometer or "ELISPOT". The ELISPOT technique is of recent discovery and it is capable to evaluate cellular frequencies in a quantitative way, through identification of cells producing IFN-gamma that characterize Th1 immune response.

The deficiency in inhibit the proinflammatory cytokines TNF-alpha, IFN-gamma, IL-2, etc., will result in cellular destruction predominance in relation to cellular protection. This phenomenon provokes serious tissue lesions, as intestinal perforation and hemorrhage. The patient's clinical condition is worse by these complications, and surgery or effective hemostasia is necessary. At this moment, the patients have profound weakness (due to high inflammatory reaction), high fever, weight loss and other clinical manifestations. The ability of clinicians and surgeons to resolve these problems has been responsible for the patients' survival.

The gastrointestinal bleeding should be attributed to endothelial cells activation through the increase of inflammatory cytokines and circulating LPS/endotoxin, mainly in the intestines. This result in high rate of endothelial cell death, and erosion of a necrotic tissue through the enteric vessel wall. The vessel basal membrane rich in collagen is exposed allowing the adherence of activated platelets. In addition, endothelial cells with the participation of pro and anticoagulation systems also activate the coagulation cascade. This microenvironment will be responsible for the bleeding and CEI death, ulcerated lesions and intestinal (usually ileal) perforation.

B lymphocytes are found in the central area of lymphoid follicles, and migrate across vascular walls together with T lymphocytes. Some lymphocytes are retained in the mesenteric lymph nodes, and they will become plasma cells in the return to intestinal mucosa's lamina propria. At this moment, these cells are capable to produce $\operatorname{IgG}$ and $\operatorname{IgM}$ immunoglobulins, as well as secretory $\operatorname{IgA}$ that is considered the first line of intestinal defense. The final molecular junction of dimeric $\operatorname{IgA}$ occurs within intestinal lamina propria. In this site, IgA receives a protecting component produced by CEIs and remains resistant to digestive enzymes. Afterwards, IgA is secreted for intestinal lumen by paracellular via, covering the mucosa surface. Together with other protectors elements of intestinal mucosa as intestinal flora, local antimicrobial, etc., the secretory $\operatorname{IgA}$ constitutes the main element of the intestinal humoral defense.

KEUTER et al. ${ }^{29}$ described the patterns of proinflammatory cytokines in 44 patients with typhoid fever, through ELISA or RIA. The circulating cytokines levels in the acute phase of disease were as follows $( \pm \mathrm{SD})$ : IL- $1 \beta=<140 \mathrm{pg} / \mathrm{ml}$; FNT- $\alpha=130 \pm 50 \mathrm{pg} / \mathrm{ml}$; IL- $6=96 \pm 131 \mathrm{pg} / \mathrm{ml}$; IL-8 $=278 \pm 293 \mathrm{pg} / \mathrm{ml}$. The authors also showed that circulating cytokines inhibitors were elevated in the acute clinical phase: IL-1 RA (IL-1 receptor antagonist $)=2304 \pm 1427 \mathrm{pg} / \mathrm{ml}$; soluble TNF-alpha receptors 55 and $75=4973 \pm 2644 \mathrm{pg} / \mathrm{ml}$ and $22,865 \pm 15,143 \mathrm{pg} / \mathrm{ml}$, respectively. In the convalescence, there was progressive decrease of cytokines in the disease recovery. Probably, the presence of cytokines inhibitors were necessary to counterbalance the high values of proinflammatory cytokines. The same authors studied the influence of blood peripheral $14 \mathrm{kDa}$ group II phospholipase A2 (PLA2) in 12 patients with typhoid fever, after admission and after recovery ${ }^{30}$. On admission, PLA2 levels were high $(1444 \pm 1560 \mathrm{ng} / \mathrm{ml})$, and decrease gradually to $55 \pm 48 \mathrm{ng} / \mathrm{ml}$ at 14th day. Patient with complicated typhoid fever had significantly higher PLA2 levels on admission $(2520 \pm 48 \mathrm{ng} / \mathrm{ml})$. The authors suggest that PLA2 may be a mediator of seriousness in prolonged inflammatory diseases such as typhoid fever ${ }^{30}$.

The extensive knowledge of typhoid fever's molecular and cellular pathogenesis, allow to all of us better understanding of its clinical phases, and more rational approach of the patient's clinical manifestations. In the future, we will be able to decrease the intensity of inflammatory phenomena, through therapeutic maneuvers intending to disable inflammatory cells (with cytokines decrease), as well as to inhibit the cellular death (hepatocytes, inflammatory cells, etc.) related to Salmonella spp. invasion.

7) Therapeutic cconsequences of typhoid fever pathogenesis: The recent concepts about typhoid fever pathogenesis described above may influence the therapeutical approach of this disease. In this way, the glucocorticoids should be used in association with antibiotics in the adults and children with severe typhoid fever characterized by high fever, delirium, obtundation, coma or shock.

Recently, a study performed in Jakarta ${ }^{9}$ showed that patients with severe typhoid fever treated with chloramphenicol and dexamethasone have lower mortality as compared to chloramphenicol group. The patients receiving dexamethasone had significant decrease of mortality from $56 \%$ to $10 \%$. In spite of the doubts about this study model, dexamethasone should be considered for typhoid fever treatment in cases with mental alterations or shock. However, glucocorticoid administration should be avoided besides 48 hours, because the increased risk of disease relapses ${ }^{11}$.

Despite of the study mentioned above, the physicians should have caution with the use of glucocorticoids associated with antibiotics in cases of severe typhoid fever, due to the recent knowledge about the mechanism of action of these antiinflammatory substances. Glucocorticoids acts in macrophages and host cells (intestinal cells, hepatocytes, etc.) through blockade of transcriptional factor NF-kB that is responsible for cytokines release as TNF-alpha, IL-1, IL-6, IL-8, IFNgamma and others. NF-kB migrates to the nucleus of infected cells, where it activates its target genes responsible for cytokines synthesis. Usually, $\mathrm{NF}-\mathrm{kB}$ is hold in inactive form by $\mathrm{IkB} \alpha$ proteins in the glucocorticoids presence, and it remains in the cytoplasm ${ }^{7}$. Some studies show that glucocorticoids increase transcription of $\operatorname{IkB} \alpha$ gene, and $\operatorname{IkB} \alpha$ concentrations go up within the cell. Other studies show that the glucocorticoid receptor complex bind to NF-kB and blockade its binding in DNA. TNF-alpha actuating through its cellular receptors TNFR-I or TNFR-II is responsible for IkB phosphorylation and its degradation through ubiquination/proteosome mechanisms, allowing the NF-kB translocation for the nucleus. In addition to cytokines synthesis, NF-kB also will be responsible for synthesis of vascular adhesion molecules (ICAMs, Selectins and Integrins), and probably also stress proteins synthesis, as well as apoptosis inhibitors (IAPs). 
Through the knowledge of molecular mechanisms of corticosteroid action, these drugs should be used in a controlled way in order to reduce inflammatory phenomena, without provoking its total inhibition. This last extreme condition would facilitate the action of Salmonella spp.?

\section{RESUMO}

\section{Febre tifóide como modelo celular microbiológico}

O conhecimento sobre a patogênese da febre tifóide vem crescendo nos últimos anos, principalmente sobre os fenômenos celulares e moleculares, responsáveis pelas manifestações clínicas desta doença. Neste artigo são discutidas várias descobertas recentes, a saber: a) $\mathrm{O}$ sistema bacteriano de secreção protéica tipo III; b) Os cinco genes de virulência da Salmonella spp. que codificam os Sips (Salmonella invasion protein) A, B, C, D e E, capazes de induzir apoptosis em macrófagos; c) A função dos receptores Toll R2 e Toll R4 presentes na superfície de macrófagos (descobertos na Drosophila). Os receptores da família Toll são críticos na sinalização mediada por LPS nos macrófagos, em associação com LBP e CD14; d) As linhas de defesa imune entre o lúmen intestinal e os órgãos internos; e) $\mathrm{O}$ papel fundamental das células endoteliais no desvio inflamatório, da corrente sanguínea para os tecidos infectados pela bactéria. Além destes aspectos, os autores comentam a correlação entre as características clínicas da febre tifóide e os fenômenos celulares e moleculares da doença, bem como as conseqüências terapêuticas deste conhecimento.

\section{REFERENCES}

1. ALIPRANTIS, A.O.; YANG, R.B.; MARK, M.R. et al. - Cell activation and apoptosis by bacterial lipoproteins through Toll-like receptor-2. Science, 285: 736-739, 1999.

2. ALIPRANTIS, A.O.; YANG, R.B.; WEISS, D.S.; GODWSKI, P. \& ZYCHLINSKY, A. - The apoptotic signaling pathway activated by Toll-like receptor 2. EMBO J., 19: $3325-3336,2000$.

3. ANDRADE, D.R.; ANDRADE JÚNIOR, D.R.; ORI, M. \& SANTOS, S.A. - Invasion of rat hepatocytes in a primary culture by Salmonella typhimurium: production of TNF alpha and analysis of the cell death. Hepatology, 30: 546A, 1999.

4. ANDRADE JÚNIOR, D.R.; ANDRADE, D.R.; SANTOS, S.A. \& ORI, M. - Timedependent progressive production of TNF-alpha for rat hepatocytes in a primary culture invaded by Salmonella typhimurium. In: INTERNATIONAL CONGRESS ON INFECTIOUS DISEASES, 9., Buenos Aires, 2000. Anais.

5. ANDRADE JÚNIOR, D.R.; ANDRADE, D.R.; SANTOS, S.A. \& ORI, M. - Analysis of the TNF-alpha production and cell death by apoptosis in rat hepatocytes invaded by Salmonella typhimurium: influence of the bacterial concentration. Hepatology, 32: 502A, 2000.

6. BALOWS, A.; HAUSLER JR., W.J.; HERMANN, K.L.; ISENBERG, H.D. \& SHADOMY, H.J. - Manual of clinical microbiology. 5.ed. Washington, American Society for Microbiology, 1991.

7. BEG, A.A. \& BALTIMORE, D. - An essential role for NF-KappaB in preventing TNFalpha induced cell death. Science, 274: 782-784, 1996.

8. BOWIE, A. \& O'NEILL, L.A.J. - The interleukin-1 receptor/Toll-like receptor superfamily: signal generators for pro-inflammatory interleukins and microbial products. J. Leuk. Biol., 67: 508-514, 2000.
9. BUTLER, T.; ISLAM, A.; KABIR, I. \& JONES, P.K. - Patterns of morbidity and mortality in typhoid fever dependent on age and gender: review of 552 hospitalized patients with diarrhea. Rev. infect.Dis., 13: 85-90, 1991.

10. CHEN, L.M.; BAGRODIA, S.; CERIONE, R.A. \& GALÁN, J.E. - Requirement of p21activated kinase (PAK) for Salmonella typhimurium induced nuclear responses. J. exp. Med., 189: 1479-1488, 1999.

11. COOLES, P. - Adjuvant steroids and relapse of typhoid fever. J. trop. Med. Hyg., 89: 229-231, 1986.

12. COSSART, P.; BOQUET, P.; NORMARK, S. \& RAPPUOLI, R. - Cellular microbiology emerging. Science, 271: 315-316, 1996.

13. ECKMANN, L.; KAGNOFF, M.F. \& FIERER J. - Epithelial cells secrete the chemokine interleukin-8 in response to bacterial entry. Infect. Immun., 61: 4569-4574, 1993.

14. ECKMANN, L.; SMITH, J.R.; HOUSLEY, M.P.; DWINELL, M.B. \& KAGNOFF, M.F. - Analysis by high density cDNA arrays of altered gene expression in human intestinal epithelial cells in response to infection with the invasive enteric bacteria Salmonella. J. biol. Chem., 275: 14084-14094, 2000.

15. GALÁN, J.E. \& COLLMER, A. - Type III secretion machines: bacterial devices for protein delivery into host cells. Science, 284: 1322-1328, 1999.

16. GALÁN, J.E. - Salmonella interactions with host cells: type III secretion at work. Ann. Rev. Cell. develop. Biol., 17: 53-86, 2001.

17. GEWIRTZ, A.T.; SIBER, A.M.; MADARA, J.L. \& McCORMICK, B.A. - Orchestration of neutrophil movement by intestinal epithelial cells in response to Salmonella typhimurium can be uncoupled from bacterial internalization. Infect. Immun., 67: 608-617, 1999.

18. GEWIRTZ, A.T.; RAO, A.S.; SIMON Jr., P.O. et al. - Salmonella typhimurium induces epithelial IL-8 expression via $\mathrm{Ca}(2+)$-mediated activation of the NF-kappaB pathway. J. clin.Invest., 105: 79-92, 2000.

19. HARDT, W.D.; CHEN, L.M.; SCHUEBEL, K.E.; BUSTELO, X.R. \& GALAN, J.E. S.typhimurium encodes an activator of Rho GTPases that induces membrane ruffling and nuclear responses in host cells. Cell, 93: 815-826, 1998.

20. HERSH, D.; MONACK, D.M.; SMITH, M.R. et al. - The Salmonella invasion SipB induces macrophage apoptosis by binding to caspase-1. Proc. nat. Acad. Sci. (Wash.), 96: 2396-2401, 1999

21. HIRSCHFELD, M.; MA, Y.; WEIS, J.H.; VOGEL, S.N. \& WEISS, J.J. - Cutting edge: repurification of lipopolysaccharide eliminates signaling through both human and murine Toll-like receptor 2. J. Immunol., 165: 618-622, 2000.

22. HOBBIE, S.; CHEN, L.M.; DAVIS, R.J. \& GALAN, J.E. - Involvement of mitogen activated protein kinase pathways in the nuclear responses and cytokine production induced by Salmonella typhimurium in cultured intestinal epithelial cells. J. Immunol., 159: 5550-5559, 1997.

23. HOFFMANN, J.A.; KAFATOS, F.C.; JANEWAY Jr., C.A. \& EZEKOWITZ, R.A. Phylogenetic perspectives in innate immunity. Science, 284: 1313-1318, 1999.

24. HOOPER, L.V. \& GORDON, J.I. - Commensal host-bacterial relationships in the gut. Science, 292: 1115-1118, 2001.

25. HORNICK, R.B.; GREISMAN, S.E.; WOODWARD, T.E. et al. - Typhoid fever: pathogenesis and immunologic control. New Engl. J. Med., 283: 686-691, 1970.

26. HOUSE, D.; BISHOP, A.; PARRY, C.M.; DOUGAN, G. \& WAIN, J. - Typhoid fever: pathogenesis and disease. Curr. Opin. infect. Dis., 14: 573-578, 2001.

27. HUECK, C.J. - Type III protein secretion systems in bacterial pathogens of animals and plants. Microbiol. Molec. Biol. Rev., 62: 379-433, 1998. 
28. JANEWAY Jr., C.A. - Approaching the assymptote? Evolution and revolution in immunology. Cold Spring Harbor Symp. Quant. Biol, 54(Pt 1): 1-13, 1989.

29. KEUTER, M.; DHARMANA, E.; GASEM, M.H. et al. - Patterns of proinflammatory cytokines and inhibitors during typhoid fever. J. infect. Dis., 169: 1306-1311, 1994

30. KeUter, M.; DHARMANA, E.; KUllberG, B.J. et al. - Phospholipase A2 is a circulating mediator in typhoid fever. J. infect. Dis., 172: 305-308, 1995.

31. KHAN, M.; COOVADIA, Y.M.; CONNOLLY, C. \& STURM, A.W. - Influence of sex on clinical features, laboratory findings and complications of typhoid fever. Amer. J. trop. Med. Hyg., 61: 41-46, 1999.

32. LEMASTERS, J.J. - Necroapoptosis and the mitochondrial permeability transition: shared pathways to necrosis and apoptosis. Amer. J. Physiol., 276: G1-G6, 1999.

33. McCORMICK, B.A.; PARKOS, C.A.; COLGAN, S.P.; CARNES, D.K. \& MADARA, J.L. - Apical secretion of a pathogen-elicited epithelial chemoattractant activity in response to surface colonization of intestinal epithelia by Salmonella typhimurium. J. Immunol., 160: 455-466, 1998.

34. MEDZHITOV, R.; PRESTON-HURLBURT, P. \& JANEWAY Jr., C.A. - A human homologue of the Drosophila Toll protein signals activation of adaptive immunity. Nature (Lond.), 388: 394-397, 1997.

35. MODLIN, R.L.; BRIGHTBILL, H.D. \& GODOWSKI, P.J. - The Toll of innate immunity on microbial pathogens. New Engl. J. Med., 340: 1834-1835, 1999.

36. MONACK, D.M.; HERSH, D.; GHORI, N. et al. - Salmonella exploits caspase-1 to colonize Peyer's patches in a murine typhoid model. J. exp. Med., 192: 249-258, 2000
37. MORRISON, D.C. \& RYAN, J.L. - Endotoxins and disease mechanisms. Ann. Rev. Med., 38: 417-432, 1987.

38. MURRAY, P.R.; BARON, E.J.; PFALLER, M.A. et al. - Manual of clinical Microbiology. 6. ed. Washington, ASM Press, 1995. p. 450-452.

39. NOMURA, F.; AKASHI, S.; SAKAO, Y. et al. - Cutting edge: endotoxin tolerance in mouse peritoneal macrophages correlates with down-regulation of surface Toll-like receptor 4 expression. J. Immunol., 164: 3476-3479, 2000.

40. OCHMAN, H. \& MORAN, N.A. - Genes lost and genes found: evolution of bacterial pathogenesis and symbiosis. Science, 292: 1096-1098, 2001.

41. SCHUSTER, J.M. \& NELSON, P. - Toll receptors: an expanding role in our understanding of human disease. J. Leuk. Biol., 67: 767-773, 2000.

42. TOBIAS, P.S.; SOLDAU, K. \& ULEVITCH, R.J. - Isolation of a lipopolysaccharidebinding acute phase reactant from rabbit serum. J. exp. Med., 164: 777-793, 1986

43. ULEVITCH, R.J. \& TOBIAS, P.S. - Recognition of gram-negative bacteria and endotoxin by the innate immune system. Curr. Opin. Immunol., 11: 19-22, 1999.

44. ZHOU, D.; MOOSEKER, M.S. \& GALÁN, J.E. - Role of the S. typhimurium actinbinding protein Sip A in bacterial internalization. Science, 283: 2092-2095, 1999.

Received: 26 December 2001

Accepted: 28 July 2003 